University of New Hampshire

University of New Hampshire Scholars' Repository

Languages, Literatures, and Cultures

Scholarship

Languages, Literatures, and Cultures

$4-25-2008$

\title{
Accomplishing marginalization in bilingual interaction: relational work as a resource for the intersubjective construction of identity
}

Holly R. Cashman

University of New Hampshire, Durham, holly.cashman@unh.edu

Follow this and additional works at: https://scholars.unh.edu/lang_facpub

Comments

This is an article published by De Gruyter in Multilingua in 2008, available online: https://dx.doi.org/10.1515/

MULTI.2008.007

\section{Recommended Citation}

Cashman, Holly R. 2008. Accomplishing marginalization in bilingual interaction: relational work as a resource for the intersubjective construction of identity. Multilingua 27 (1-2): 129-150.

This Article is brought to you for free and open access by the Languages, Literatures, and Cultures at University of New Hampshire Scholars' Repository. It has been accepted for inclusion in Languages, Literatures, and Cultures Scholarship by an authorized administrator of University of New Hampshire Scholars' Repository. For more information, please contact Scholarly.Communication@unh.edu. 


\title{
Accomplishing marginalization in bilingual interaction: Relational work as a resource for the intersubjective construction of identity*
}

\author{
HOLLY R. CASHMAN
}

\section{Abstract}

This paper examines the use of impoliteness by Spanish-English bilingual pre-adolescents as a resource for accomplishing identities in spontaneous conversational interactions in an elementary school setting. The theoretical approach employed integrates the concept of relational work (Locher 2004; Locher and Watts 2005), which is based on Goffman's (1967) notion of face and which privileges participants' evaluation of language behavior within the norms of the community of practice, with recent work in sociocultural linguistics (Bucholtz and Hall 2004a, 2004b, 2005). This approach views identity as an interactional achievement reached through the use of what they call tactics of intersubjectivity. In this analysis, negatively marked, non-politic behavior is viewed as an interactional resource, which, along with other resources such as codeswitching, bilingual speakers may employ for the purposes of alignment and stance-taking. Specifically, the paper examines how speakers use strategies referred to as impolite ( $c f$. Culpeper 1996) in the performance of a variety of tactics of intersubjectivity to manage local identities (e.g., leader/follower, insider/outsider) as well as membership in broad social categories (e.g., gender, ethnic identities) in interaction, how they engage in conflict talk and what they gain from it, and how codeswitching is (and is not) used in interactions. This analysis is situated within the wider social context of language politics and immigration politics in the individual school, the region, and the US.

\section{Introduction}

The superiority of English and the marginalization of languages other than English are key elements of the standard language ideology in the US (Lippi-Green 1997). Hardly limited to speakers of so-called Standard American English alone, this ideology is subscribed to by speakers of languages other than English as well, with deleterious effects on the 
maintenance of minority languages, support of minority language education and bilingual education, and linguistic self-esteem among speakers of minority languages (cf. García Bedolla 2003). As Lippi-Green points out, schools are one of the four main sites of linguistic discrimination, and one of the places that children are taught to discriminate against minority languages and accents both foreign and domestic. Discrimination against minority languages in schools has been documented in a variety of bilingual and multilingual contexts throughout the world, including the US Southwest (cf. MacGregor-Mendoza 1998a). While research in this area of linguistic discrimination has traditionally examined the topic at the level of language policy (cf. Trujillo 2005) and teachers' language attitudes (cf. Weisman 2001, MacGregor-Mendoza 1998b), this analysis aims to demonstrate that even in peer interaction in a dual language immersion bilingual school, marginalizing practices may be used to exclude participants from a bilingual community of practice in ways that are potentially consequential not only for the social development of the children involved but also for students' academic achievement and educational opportunities.

\section{Review of the literature}

The subject of identity in interaction has been of great interest to sociolinguistics and sociolinguists since the early days of the field (cf. Labov 1963, 1966), although identity as social practice and as a product of social interaction has replaced fixed notions of social categories such as race, social class, sex, and age, to name a few (cf. Schilling-Estes 2004; Eckert and Rickford 2001; Eckert 2000). It has been observed that switching between two (or more) language varieties may be used as a resource by bilingual speakers in order to manage identities in interaction. Codeswitching, or the juxtaposition of distinct language varieties, while quite noticeable, especially to outsiders and monolinguals, is not the only interactional resource for identity construction available to bilingual speakers. Auer's (1984) description of codeswitching as a contextualization cue (Gumperz 1982) stressed the point that codeswitching is one of many resources available to bilingual speakers. Just as monolinguals do, bilingual speakers may use a wide variety of interactional resources in conversation (cf. Gumperz and Gumperz 2005). Because the literature on bilingual speakers and identity construction is too extensive to go into here, I will only state briefly that this paper is informed by the conversation analytic approach to bilingual conversation advocated by Li Wei (2005). 'What we need,' he writes, 'is a dual-level approach, which links, in a principled and systematic way, the sequential analysis of code-switching in conversation to the rational choice analysis of social 
motivations' (ibid:: 387). ${ }^{1}$ This approach holds that, rather than linguistic structure merely reflecting social structure, social structure and linguistic structure are mutually constitutive, and that it is the analyst's task to demonstrate that extra-linguistic context is relevant to participants as well as procedurally consequential for the interaction (ibid.: 382).

In this paper, I will demonstrate that what has been termed impoliteness in recent research on the topic, like codeswitching, is one of the interactional resources bilingual speakers may use to do identity work in conversation. While research on impoliteness has increased in the decade since Culpeper's (1996) seminal article on the topic, it is rarely discussed in relation to identity work. There are, however, a few studies that approach the topic of politeness or impoliteness and identity in bilingual interactions. Gardner-Chloros and Finnis (2003), for example, examine codeswitching, gender, and politeness in London's Greek Cypriot community. They find that the women they observed seemed to use codeswitching as a resource for mitigating direct speech acts perhaps considered unfeminine, especially in interactions with men (ibid.: $528-$ 529). Cromdal (2004) examines bilingual children's construction of oppositional stances in interaction. He finds that the bilingual children whose interactions he analyzed used codeswitching to create, maintain and, especially, escalate opposition; in addition, he finds that a variety of other resources were also used to accomplish opposition including sequencing (overlapping, latching), polarity markers, prosodic cues, and bodily stance (ibid.: 53). Evaldsson's (2005) study of insults and categorizations in bilingual, pre-adolescent boys and Pichler's (2006) study of teasing among adolescent girls are perhaps closest to what I aim to do in the present analysis. Evaldsson examines how a local masculine order is produced through the language practice of insulting, specifically boys' design of insults, recipients' response to insults, and the categorization of recipients vis-à-vis broader concepts of social class, ethnicity, gender, and education (2005: 766). She finds that insults are not an isolated speech activity, but that they are constructed sequentially and collaboratively by participants, as are the responses to insults. In addition, she finds that insults utilized negative descriptions that made relevant group membership and ethnic or institutional identities. Her study thus integrates the research threads of bilingual interaction, identities, and, although not explicitly, impoliteness. Likewise, Pichler's (2006) examination of teasing among British Bangladeshi adolescent girls brings together research on gender, identities, and, again not explicitly, impoliteness in a multilingual setting. She finds that, while teasing for the purpose of group bonding and friendship is the most common, teasing is also used as a face threat, to create a local 'tough' identity and to index 'membership in British working-class youth culture' (ibid.: 244). ${ }^{2}$ 


\section{Theoretical approach}

The theoretical approach to the data analyzed below consists of the integration of the concept of relational work (Locher and Watts 2005) and the sociocultural linguistic approach to identity (Bucholtz and Hall 2005). Relational work attempts to contextualize interactional behavior that analysts refer to as 'polite' or 'impolite' within a broader spectrum of interaction, providing a more complete, more nuanced way of examining co-participants' management of interaction than the study of politeness, in the Brown and Levinson (1987) theory, or impoliteness, in the Culpeper (1996) model. The continuum of interaction described by relational work stretches from the impolite (negatively marked and inappropriate) to the polite (positively marked and appropriate), to the overpolite (negatively marked and inappropriate) (Locher 2004: 90). Locher and Watts rely on Goffman's (1967) notion of the frame as well as Bourdieu's (1990) notion of the habitus in order to 'account for the structuring, emergence, and continued existence of social norms which guide both verbal and non-verbal instances of relational work' (Locher and Watts 2005: 10). They dispense with the idea of achieving a universal theory of politeness because participants in interaction, they argue, are engaged in a discursive struggle over concepts like polite, normal, appropriate, and rude. Instead, they advocate the study of that very discursive struggle through a close examination of conversational interaction, taking into account the context of the interaction, participant-defined norms, and participants' conflict over what is and is not appropriate.

Relational work, like other recent approaches to politeness and impoliteness, is marked by several key departures from the traditional politeness theory of Brown and Levinson (1987). ${ }^{3}$ First, new approaches to (im)politeness, including relational work, broaden the focus of their analyses from the utterance level to longer stretches of talk-in-interaction. Second, they re-situate the concepts of politeness and impoliteness as a participant-defined (rather than an analyst-defined) phenomenon. Third, they recognize to a certain extent the role of the hearer and the context, either of the community or practice or the activity type, in defining what is and is not polite/impolite.

While the relational work approach is not compatible with Culpeper's (1996) original model of impoliteness because of the latter's reliance on Brown and Levinson's (1987) theory, its focus on the speaker's intention to the exclusion of the hearer, and the focus on the identification of impoliteness strategies, which necessarily vary from community to community, later iterations of Culpeper's approach (Culpeper 2005; Culpeper et al. 2003) are increasingly nuanced and less dependent on Brown and Levinson. Most recently, Culpeper (2005) defined impoliteness as a 
speaker's intentional attack of her or his interlocutor's face or a hearer's perception or construction of behavior as an intentional face attack (or both) (2005: 38). Thus, he highlights the co-constructed nature of impoliteness, rejecting the notion that any utterance is inherently polite or impolite and emphasizing the importance of the participants' social relations and the activity type associated with the interaction (ibid.: 41). Similarly, in relational work, impolite behavior is defined as negatively marked, impolitic, and inappropriate for a given situation, community or interaction.

In the present paper, negatively marked, impolite, and inappropriate talk is viewed as an interactional resource, which, in addition to other resources such as codeswitching, bilingual speakers may employ for the purposes of identity construction and negotiation. This new approach to impoliteness is brought together here with new approaches to identity, encompassed in Bucholtz and Hall's framework (Bucholtz and Hall $2005,2004 a, 2004 b)$, in which identity is viewed as an interactional achievement. Bucholtz and Hall (2005) propose five principles for the analysis of identity in interaction, which I will briefly summarize here: first, EMERGENCE describes the view that identities are realized (that is, made real) through interaction (ibid.: 591); second, POSITIONALITY captures the importance of interactants' locally-situated, temporary roles and their fleeting but cumulatively significant positions vis-à-vis their coparticipants in the emergence of identities (ibid.: 591-593); third, INDEXICALITY traces the indexical processes participants employ and exploit in order to make social meanings via linguistic forms, from explicit mention of identity labels to use of structures associated with certain speakers (ibid.: 594-595); fourth, RELATIONALITY highlights the intersubjectivity of identities in interaction and their positioning on multiple, overlapping dimensions including (from Bucholtz and Hall 2004a and 2004b), adequation/distinction (or similarity/difference), authentication/denaturalization (or realness/artifice), and authorization/illegitimation (or power/disempowerment) (ibid: : 598-599); ${ }^{4}$ finally, PARTIALNESS indicates that any account of identity is necessarily incomplete given the nature of the researcher/researched relationship as well as the situatedness of identity construction and negotiation (ibid.: 605-606). This model has been used to examine identity construction and negotiation in cross-ethnic appropriation (cf. Reyes 2005, 2007), but not in bilingual contexts. ${ }^{5}$

\section{Setting, participants and methods}

Building on a tradition of research in Spanish-English bilingual interaction in the US Southwest, this paper examines the use of impoliteness as a resource for constructing and negotiating identities in spontaneous 
interactions of pre-adolescent Spanish-English bilingual children involved in collaborative activities in an elementary school in Phoenix, AZ, a linguistically diverse urban center and the fifth largest metropolitan area in the US. Conversation analysis is combined here with an ethnographic approach. As the fieldworker as well as the analyst, I spent several days a week over the course of an academic year in one bilingual, dual-immersion class that alternated between two teachers. Although I initially attempted to avoid the role, the participants naturally oriented to me as a teacher's aide, one of the many types of para-professionals that frequented their classrooms. Despite this assigned role, I attempted, as much as possible, to avoid interacting with the students being recorded, preferring to leave the mini-disk recorder on a table where students were interacting collaboratively and retreat to another area of the classroom to work with other students. The data consist of 25 hours of audio recordings of spontaneous interactions among 22 students in a second grade, bilingual classroom in an urban elementary school whose student population was $90 \%$ Hispanic. $^{6}$

\section{Data and analysis}

In the first set of excerpts, four main interactants participate: three students and the author (FW). The three students, Jessica, Marta, and Andrés are sitting at a table in their English language classroom and their task is to make Valentine's Day cards. ${ }^{7}$ They have been given few instructions from the teacher, but they have a variety of art supplies and other resources at their disposal. Jessica and Marta are both bilingual students who seem to display a trans-episodic preference for Spanish. While students in the class varied in terms of their length of residence in the US, with some being US born and others arriving more recently, Andrés was the most recently arrived student from Mexico. Andrés had very limited productive skills in English, and he was required to spend the entire school week in the English classroom language immersion environment rather than participate in the bilingual, dual immersion program with the rest of the students in the class. ${ }^{8}$ In the excerpts that follow, we will investigate how participants construct their identities visà-vis Andrés, and how they use relational work as a resource for doing identity work.

In excerpt (1), Jessica and Marta negotiate control over a pair of scissors, the only one in the classroom that cuts zig-zag edges. Andrés works alongside them, often asking the fieldworker for help:

Excerpt (1): ${ }^{9}$

1 Jessica: pásamelo ay déjame hacer un corazón pass me it oh let me make a heart 
2 Marta: deja- no más hago esta línea okay?

let- I'll just do this line okay?

$(0.5)$

3 Marta: y luego ya te lo presto and then I'll lend it to you already

(1.0)

$4 \quad$ Marta: $\quad$ voy a hacer una bonita carta

I'm going to make a pretty card

5 Jessica: no:: quiero hacer éste mira

no:: I want to do this look

(4.0)

$6 \quad \mathrm{FW}$ (to $\mathrm{J})$ : are those special scissors?

7 Jessica: ((demonstrates zig-zag))

8 FW (to A): oh (.) sí ellas- son tijeras: son tijeras especiales

así que- hay que pedirle a (Jessica)-

oh yes they-are special they are special scissors

so that-one has to ask (Jessica)

9 Jessica: las estamos usando maestra (.) él puede usar ellas para allá we are using them teacher he can use those over there

[CD4_15]

At the outset of this interaction, Jessica and Marta have constructed oppositional stances with regard to a coveted resource - the special scissors. Both interactants want control of the resource and both attempt to achieve this control through relational work. In turn 1, we see Jessica attempt to assert her control by issuing two unmitigated direct requests. In this community of practice, unmitigated direct requests like those in turn 1 are politic and unremarkable, as one can see by Marta's response in turn 2, which does not orient to Jessica's turn as problematic or nonpolitic in any way. Marta's response in turn 2 and subsequent turns 3 and 4 comprise an attempt to maintain control of the scissors using a variety of linguistic resources. While one might expect the rejection of a request to be marked as a dispreferred second pair-part, Marta's response is relatively unmarked. She responds to Jessica's request without delay and, although she self-repairs and changes strategy partway through turn 2, she swiftly denies Jessica's request or at least delays it significantly. In turn 2, Marta self-corrects her initial use of a directive, repairing it with a simple declarative utterance stating her plans to use the scissors. Although not a request, this utterance is mitigated in two ways: Marta uses the expression 'no más', which diminishes the impact of the declaration of her intent not to comply with Jessica's request, and she uses the token 'okay' to attempt to elicit cooperation. This is followed in turns 3 and 4 with two more declarative utterances, the first promising compliance with Jessica's request in the future and the second shifting the topic to her plans for her card. Jessica orients to Marta's attempt to control the scissors as unacceptable, first by refusing to de- 
liver the agreement token Marta tried to elicit at the end of turn 2, second by refusing to respond during one second to Marta's promise of future compliance in turn 3 , and third with the use of an elongated polarity marker at the start of turn 5 and the use of another, this time indirect, request. Marta's success at maintaining control of the resource can be intuited from the four-second silence that followed, during which it can be assumed she is still using the scissors.

This opposition created by Jessica and Marta over control of a valuable classroom resource, in which both tried to construct a stance of ownership, or at least rightful 'usership' of the scissors, is quickly neutralized when a third party attempts to gain access to them. The fieldworker, having been asked by Andrés in side talk, inquires of Jessica about the status of the scissors. In turn 9 Jessica, in response, aligns herself with Marta, using the first person plural pronoun and constructs a new opposition with Marta and herself on one side, as legitimate users of the scissors, and Andrés on the other, as someone who does not have access to them. Here, Jessica indicates that despite their conflicting stance over who ought to control the use of the scissors, she and Marta are in some sense united in their locally constructed role of (sole) rightful users of the resource in opposition to Andrés.

In the following excerpt, which follows soon after excerpt (1), Andrés attempts to assert his right to the scissors and minimize the opposition constructed by Jessica and Marta. He does so not directly with the two girls, but through a third classmate who requests the scissors:

Excerpt (2):

1 Jessica: duele mucho para cortarlo

it hurts a lot to cut it

2 Girl: (I want to use the scissors) after you

3 Andrés: ey yo voy enseguida

4 Girl: you?

Jessica, now using the scissors, in turn 1 displays her control over the resource, remarking on how cutting the paper hurts. ${ }^{10}$ As she is doing so, another student approaches the table and requests the scissors. ${ }^{11}$ Andrés orients to her turn as inappropriate and asserts his stance toward the scissors, implicitly aligning himself with Jessica and Marta as Jessica did explicitly in excerpt (1). The student, who was not assigned to the same worktable and who had not been waiting for the scissors, seems to express surprise at Andrés' claim. Of course, a variety of explanations could be justified here for the girl's response. One, for example, might be that she assumed that Andrés, as a boy, would have no interest in the 
scissors, as the boys tended to engage less enthusiastically in arts and crafts projects. Another possible explanation, however, when seen in a broader context of Andrés' marginal membership in the community of practice, might be his lack of claim on community resources, which is one way that his fellow students construct his otherness or practice distinction. ${ }^{12}$

This can be seen further in excerpts $(3-5)$ :

Excerpt (3):

1 Jessica: voy a hacer el [corazón

I'm going to make the heart

2 Miss Sarah: [okay let (A)- let (Andrés) use the scissors now

3 Jessica: but I need to make the heart=

4 Andrés: =ey yo quiero hacer el corazón (.) voy a hacer el deste

hey I want to make the heart (.) I am going to make this thingy

[CD4_15]

Excerpt (4):

1 Girl: where's the [pair of scissors at?

2 Jessica: mira maestra

look teacher

3 FW: (.h) ay [qué linda la carta

oh what a pretty card

Girl:

[no where's the scissors- where's the scissors the other ones

5 Mar: WE ARE USING IT

6 Girl: no where are the scissors like this?

7 Mar \& Jess: WE (.) ARE (.) U::SI::NG IT ((banging on table))

8 Girl: $\quad{ }^{\circ}$ I need them ${ }^{\circ}$

9 Jessica: you have to [wait

10 FW: [well he's waiting first so after he's done you can ask

11 Marta: no he- [he wasn't using it teacher

12 Jessica: [he's not next

[CD4_16]

Excerpt (5):

1 Andrés: ahorita me prestan las tijeras eh?

now will you lend me the scissors?

(3.0)

2 Andrés: bueno a lo mejor dibujo un corazón y le corto así

[CD4_16]

well I guess I'll draw a heart and cut it like this

In excerpt (3), the student teacher, Miss Sarah, intercedes on Andrés' behalf. Just as the fieldworker's attempt in turn 8 of excerpt (1) was rejected by Jessica, the student teacher's is here. This is seen again in 
excerpt (4), where Marta and Jessica in turns 11 and 12 collaborate to reject the fieldworker's attempt to secure the scissors for Andrés. Finally in excerpt (5), Andrés directly addresses Jessica and Marta in an effort to attempt to secure access to the scissors. The three-second pause following his request, which sets up the expectation for a response, is, in most cases, highly marked. Silence where a response is expected may indicate a negative response, which, as Andrés' utterance in turn 3 clearly demonstrates, is his interpretation of the silence.

The exclusion of Andrés from the community of practice as seen in excerpts $(1-5)$ and the emergence of his locally achieved 'outsider' or 'marginal' identity is a product of the repeated alignment of students with each other and opposing him with relation to the scissors are further reinforced through the use of other types of relational work. In excerpt (6) below, we see the use of two marked strategies, threatening and insulting, in an interaction involving the same three core participants from the excerpts above and two additional bilingual, female participants, Cari and Melissa:

Excerpt (6):

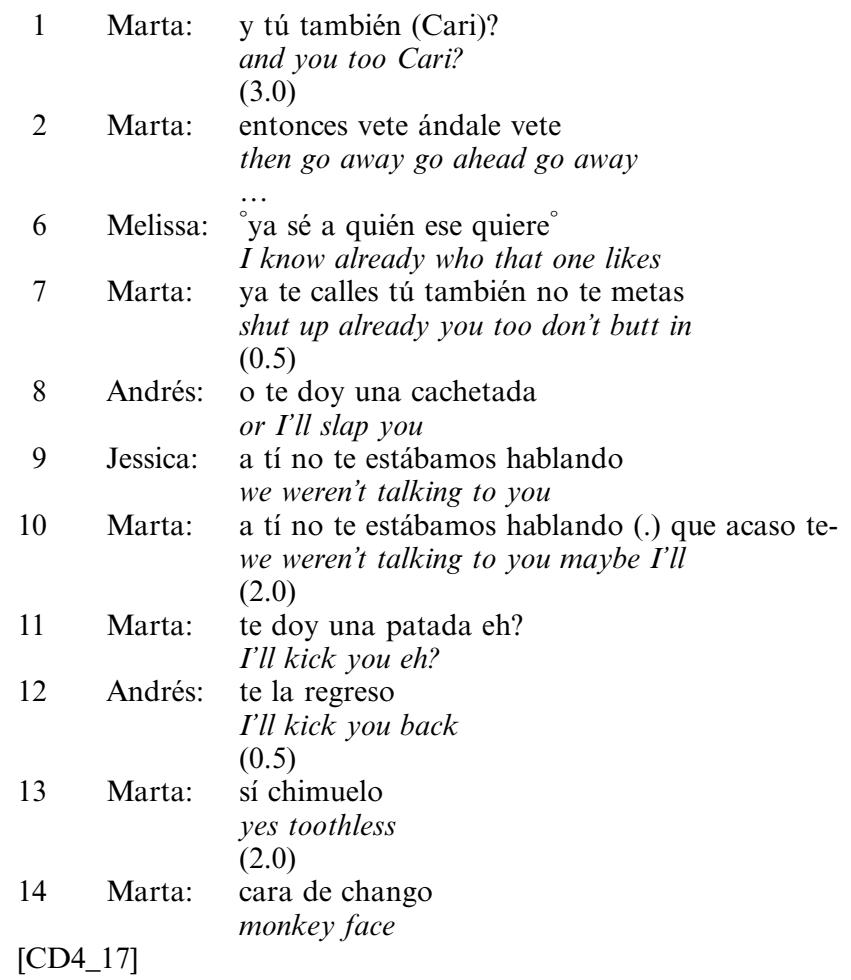


At the outset of the above excerpt, Marta expresses surprise that Cari also wants to use the scissors; she tells Cari to go away and, implicitly, denies her access to the scissors. In turn 6 Melissa, perhaps in an attempt to create solidarity with Marta and thereby improve her chances at gaining access to the scissors, tells Marta, very quietly, that she knows an item of gossip presumably of some interest. Marta, however, rejects this move by Melissa and, in fact, seems to chastise her for gossiping, orienting to her earlier utterance as inappropriate 'butting in' in turn 7. Andrés orients to Marta's utterance as marked (perhaps nonpolitic) and, in turn 8 , he makes a threat of physical violence. Andrés' turn 8 is ambiguous in that there are at least two possible interpretations of what his utterance indicates about his understanding of turn seven, and also in that there are, consequently, at least two possible interpretations of what Andrés himself is doing in his turn. On the one hand, it is possible that Andrés considered Marta's previous utterance to be directed towards him. If that is the case, Andrés responds offensively to Marta's rebuke with a threat of physical violence toward her. On the other hand, Andrés may have interpreted Marta's utterance as a rejection of Melissa's attempt to create solidarity, in which case his threat of physical violence (towards Melissa, in this interpretation) either serves as an attempt to align himself with Marta and against Melissa or as an attempt to mock Marta's marked, nonpolitic behavior by voicing Marta threatening Melissa. The initial $o$ ('or') would seem to favor the interpretation that Andrés is collaborating in finishing Marta's previous turn and directing the threat toward Melissa. Regardless of Andrés' interpretation and intention in turn 8 , in turns 9 and 10 Jessica and Marta collaborate to reject his attempt to enter the interaction. Jessica, using the first person plural pronoun, aligns herself with Marta and constructs an opposition between what they are doing and what Andrés is doing: they are part of the conversation (even though Jessica had not contributed anything in several turns) and he is not. Marta, echoing Jessica's turn by copying her word choice exactly, aligns herself with Jessica and against Andrés. She follows this with a threat initiated in turn 10 and, interrupted by a two-second pause, realized in turn 11. Andrés responds offensively (cf. Culpeper et al. 2003) in turn 12 returning Marta's threat of physical violence. Marta responds to Andrés' threat with two turns of namecalling, using two insult terms that may also serve to index broader social meaning, such as ethnoracial categorization or membership in a lower social class. While Marta, compared to other students in the class, was also relatively poor and had darker skin, she uses impoliteness here to produce difference and neutralize sameness. Both name-calling and threats of physical violence are marked, inappropriate behavior in the community of practice. These types of attacks violate the teachers' rules 
regarding acceptable behavior, which leaves students who use them vulnerable to threats to tell the teacher. They are also remarkable, in that they are often commented on by participants. Because of this marked status they can therefore be used to draw attention to and aggravate participants' turns. In the case of Marta's insult terms here, they both serve to construct difference (distinction) between Andrés and the speaker, in this case physical distinction. Andrés does not respond to this use of marked, inappropriate behavior, and Marta opts not to upgrade her insult a third time.

Excerpt (7), which does not come from the same Valentine's Day card activity, but rather from a class field trip to the zoo, also exemplifies the use of name-calling to exclude Andrés. Although Andrés is part of the group of students at the zoo, it is unclear whether he is close enough to hear the interaction, including turn 4, between Marta and Cari below:

\section{Excerpt (7):}

\begin{tabular}{|c|c|c|}
\hline 1 & Marta: & $\begin{array}{l}\text { pobre enano } \\
\text { poor dwarf }\end{array}$ \\
\hline & Cari: & enano \\
\hline 3 & Marta: & $\begin{array}{l}\text { sí parece enano } \\
\text { yes he seems like a dwarf } \\
(0.5)\end{array}$ \\
\hline 4 & Marta: & $\begin{array}{l}\text { oye enano } \\
\text { hey dwarf }\end{array}$ \\
\hline 5 & Cari: & $\begin{array}{l}\text { así le dicen } \\
\text { that's what they call him }\end{array}$ \\
\hline
\end{tabular}

Just as the name-calling from excerpt (6) serves to mark Andrés as different, so does the use of the same strategy in excerpt (7). This time, his physical size, instead of the size and layout of his teeth or the shape and color of his face, is the object of ridicule and the resource for constructing difference.

Excerpt (8) that follows is a longer stretch of talk in which two participants, Cari (from excerpts [6] and [7]) and Jordan, a bilingual boy, use a combination of marked, impolitic strategies to do distinction in an interaction with Andrés. While excerpts (1-7) exemplify the bringing about of local, intersubjective identities such as 'insider' and 'outsider' or 'core member' and 'marginal member', excerpt (8) demonstrates how participants bring broader, ethnic/national identities into an interaction in order to do identity work:

Excerpt (8):

1 Jordan: a ver qué dice todo aquí dice aquí let's see what all this here says it says 
2 Andrés: (cómo dice aquí)

(what does it say here?)

3 Jordan: cómo dice aquí? cómo te llamas?

what does it say here? what's your name?

4 Cari: (Andrés)

5 Jordan: aquí dice (Andrés) es un tonto

here it says Andrés is an idiot

6 Andrés: y aquí dice cómo te llamas?

and here it says what is your name?

7 Jordan: nada

8 Andrés: cómo se llama? (Jordan) es un burro cara de tacuachi

what is his name? Jordan is a rag-faced mule

9 Cari: tú porque tienes tu sonrisa hasta acá

you are because you have your smile up to there

10 Andrés: dámelo dile que me lo dé

give it to me tell him to give it to me

11 Cari: dile que me lo dé ((whining, high pitch))

tell him to give it to me

12 Andrés: no me quiere dar el lápiz

he doesn't want to give me the pencil

13 Cari: ni sabe inglés

he doesn't even know English

14 Jordan: ni sabes inglés

you don't even know English

15 Andrés: o le digo a la maestra que le diga

oh I'm telling the teacher to tell him

16 Cari: el orejudo éste eres tú patiando la pelota

this big eared one is you kicking the ball

17 Jordan: ey

hey

18 Andrés: tú eres éste es (Jordan)

you are this one is Jordan

19 Jordan: qué?

what?

20 Melissa: con un vestido se dibujó

with a dress he was drawn

23 Jordan: cómo hablas ay güey ((mimicking Andrés))

how you speak hey dude

24 Andrés: le voy a decir a la teacher

I'm going to tell the teacher

25 Cari: no se dice teacher (.) te acuerdas ayer

que estabas diciendo teacher?

you don't say teacher do you remember yesterday

that you were saying teacher?

[CD4_5]

Prior to the interaction excerpted here, the monolingual English teacher had assigned Jordan and Cari to help Andrés, whose productive skills in English are very limited, with the English writing assignment. Therefore 
Jordan initiates the interaction seemingly in a helping orientation toward Andrés in turn 1 and Andrés in turn 2 orients to this. In turn 3, Jordan echoes Andrés' previous turn, which signals his shift away from a helping orientation to setting up, collaboratively with Cari, an attack on Andrés. Andrés is perhaps aware of this shift on Jordan's part, given that he does not answer Jordan's question. Jordan's echoing of Andrés' question serves to mock him and highlight his vulnerability and dependence on the other students. In the same turn, Jordan asks Andrés for his name, which Cari provides. This move is collaborative, as Cari aligns herself with Jordan. Whether Jordan does not know Andrés' name in a classroom where everyone knows each other's names or whether he feigns ignorance in order to exclude Andrés and question his membership in the community is not clear; the result, however, is the same. In turn 5, Jordan, voicing the authoritative voice of the book they are supposed to be writing about attacks Andrés via name-calling. In this community, name-calling regarding a person's intelligence (e.g., mensola, 'stupid') was very marked and oriented to as highly inappropriate or impolitic by participants (cf. Cashman 2005a). In turn 8, Andrés responds offensively to Jordan's attack using name-calling to insult Jordan's appearance. Both Cari and Jordan respond: Cari counters Andrés' attack by claiming that Andrés' insult applies to him and not Jordan, and Jordan by escalating the interaction, physically invading Andrés' territory, and, in a move reminiscent of the scissors in excerpts $(1-6)$, refusing to let him use the pencil, a group resource. In turn 10, Andrés directly requests the pencil from Jordan and then attempts to elicit Cari's help. Cari, however, initiates a subsequent attack on Andrés, implicitly bringing the notion of national origin via language proficiency into the interaction. First, she echoes Andrés' previous turn, using a whining, high-pitched intonation. Then in turn 13 she attacks his linguistic ability, highlighting the linguistic proficiency difference between Andrés, who is considered Spanish monolingual and Cari and Jordan, who are considered bilingual. Jordan escalates the attack in turn 14 - whereas Cari used the third person, Jordan addresses Andrés directly with the second person singular. In this way, Jordan and Cari again collaborate to ridicule Andrés' lack of English proficiency. Andrés responds by threatening to report Jordan and Cari to the teacher, a threat that is for all intents and purposes empty, as the teacher does not speak Spanish. Not swayed by this threat, Cari in turn 16 attacks Andrés' appearance, similar to the attacks in excerpts $(6-7)$, pointing to a drawing in the book the students are assigned to write about. Andrés responds by physically taking the book from Cari, and in turn 18 by attacking Jordan's face by comparing him to one of the drawings in the book, a girl in a dress. Jordan in turn 23 ridicules Andrés' variety of Spanish. Andrés again threatens to tell 
the teacher, and finally, in turn 25, Cari ridicules Andrés' hispanicized pronunciation of 'teacher'.

In this excerpt, both Cari and Jordan use a variety of marked, nonpolitic strategies for the purpose of distinction, that is, to produce difference. Through their use of name-calling, mocking and ridicule, physical aggression, and attacks on Andrés' English and Spanish, they mark Andrés as different from them, as an out-group member, and they index his national origin (or lack of time in the US) and social class. Through their collaboration in the attacks on Andrés, Cari and Jordan also succeed in constructing between themselves a sense of sameness, that is, in accomplishing adequation. Through their joint impoliteness toward Andrés, they accomplish the local identities, however fleeting, of in-group members. Andrés' attempts to resist this identity work in excerpt (8) by attempting to get Cari to align herself with him, and by using some of the same strategies (name-calling, physical aggression) (cf. Zentella 2003 on resistance). His attack on Jordan in turn 18, for example, attempts to construct difference between him and Jordan in a way that would disrupt or destabilize Jordan's masculinity and highlight his own toughness.

Bucholtz and Hall (2005) point out that the three pairs of relations are not mutually exclusive and that it is not uncommon for two or more relational processes to work simultaneously and in conjunction. It is clear that while attempting to accomplish the in-group and out-group identities in excerpt (8), Cari and Jordan also make use of a second relational process, namely illegitimation. By calling into question Andrés' English proficiency and by ridiculing his pronunciation of an English word, they position Andrés as an incompetent speaker of English (ergo a Spanish monolingual). By ridiculing Andrés' way of speaking Spanish through use of the iconic word güey, they also index his Mexican (as opposed to Mexican American) identity and position him as a speaker of a non-prestige variety of Spanish. In doing so, they simultaneously accomplish their identities as competent, bilingual speakers of Spanish and English, vested with the authority to judge pronunciation of both English and Spanish, and highlight Andrés' foreignness. ${ }^{13}$

It is perhaps worthwhile to remark here on the exclusive use of Spanish in the interaction, except for Andrés' use of the word 'teacher' and Cari's repetition of it. This is notable, given that Cari and Jordan are both bilingual and Andrés is monolingual in Spanish. Because of this difference in language proficiency, switching to English, it would seem, would have been an easy way to accomplish and/or highlight the distinction between Andrés on one side and Cari and Jordan on the other. Instead, Cari and Jordan choose to maintain Spanish throughout the interaction and rely on other resources, including impoliteness strategies, to do distinction and adequation, illegitimation and authentication. This 
choice is likely due to two main factors: first, many of the strategies employed (e.g., name-calling) depend on an interactant's comprehension to be effective, therefore maintaining Spanish meant assuring that Andrés understood that he was being excluded; second, given that the interaction took place in the English language classroom with an English monolingual teacher and an English monolingual teaching assistant, the maintenance of Spanish throughout the interaction guaranteed their impunity - they could not be held responsible for transgressing the teacher's (or school's) rules if the teachers couldn't understand.

The ninth and final excerpt included here is different from the mainly peer interactions of the previous excerpts. Rather, in excerpt (9), we see the English language classroom teacher speaking to the whole class:

\section{Excerpt (9):}

1 Miss K: umm, how could-how could you do better to help your team? what do you think? how-how could you do better to help your team? (1.0) wh- what's a good team? what makes up a good team?

(2.0)

2 Miss K: when you guys are working together? what?

3 Girl: don't fight

4 Miss K: yeah, don't fight. (0.5) try to get along because then you spend time fighting and guess what happens?

5 Girl: [(it falls)

6 Girl2: [it messes [up

7 Miss K: [I've seen more people fight [and then they have nothing

8 Boy: [fight

9 Miss K: in front of them (0.5) because they've just spent so much time arguing about-who's gonna cut the tape (1.0) or whatever it may be

10 Miss K: go ahead

11 Student: don't fight with the team

16 Miss K: if I see you doing something else (0.5) that tells me you don't want to be a part of your team

(1.0)

17 Miss K: and you're not helping

13 Student: ((gasps))

14 Miss K: umm what?

15 Jessica: like (Andrés) was

16 Miss K: yeah but we're not- we're not going to tell unless it's a good thing [CD1_35]

In this excerpt from the teacher's instructions to students before they begin a collaborative activity, we see the teacher's attempt to influence what is and is not acceptable behavior in the community of practice or for the specific activity type (cf. Levinson 1992) of collaborative work. This not only gives us insight into how the teacher attempts to shape the 
norms of the community of practice, but it also informs our understanding of how students' local identities, produced in interaction, become more stable, trans-episodic identities that can be then brought along into subsequent interactions. Jessica's insertion of Andrés as an example of someone who fights and is disruptive to successful, collaborative group work is ratified by the teacher, although she then cautions that saying things about others that are not positive or complimentary is also a transgression of the community norms imposed by the teacher.

What the excerpts indicate overall is Andrés' exclusion from anything but marginal participation in the community of practice by his peers, who construct him as 'other' using relational work (e.g., impolite, negatively marked, and inappropriate talk) that contributes to distinction, or the identity work strategy involving the manufacture of difference. The social context of the English language classroom allows for these activities to be carried out with impunity, as neither the teacher nor the student teacher understand Spanish, and they are in fact facilitated by the practice of pairing Andrés with bilingual students and making him dependent on them for his learning. Finally, Andrés' efforts to resist and contest this construction are thwarted by the teacher-imposed norms of the community of practice, which he transgresses in using threats of violence, perhaps the only strategy accessible to him given the circumstances. In turn, in the final excerpt, we see how this begins the construction of Andrés as a 'problem student', or a student unwilling or unable to follow the rules of the community. This designation has very real effects on the academic opportunities, educational development, and life chances of students who are tracked based on behavioral as well as academic criteria. In this way, we see how the teachers (and a fieldworker) who are unable or unwilling to create a nurturing environment or even simply ensure fair treatment for students like Andrés, and who penalize them for aggressive behavior but do not sanction the behavior of other students toward them, are participating in the systematic exclusion of some of the most vulnerable students in the educational system.

\section{Conclusion}

Although politeness and impoliteness have traditionally been seen almost exclusively in terms of community norms or in terms of membership in broad social categories (sex, nationality), I have attempted to show through this analysis of the interactional, intersubjective emergence of marginality that relational work may be used as a resource for accomplishing identities locally in interaction. The accomplishment of identity in interaction has been examined here via the lens of the sociocultural linguistic framework described by Bucholtz and Hall (2004a, 
2004b, 2005). In the present analysis, the principle of emergence, or the realization of identities in interaction, was exemplified in the case of Andrés, whose identity as outsider, foreigner, and marginal community member emerged through the interactions with his peers. Though fleeting, the interactions and the roles of the students vis-à-vis Andrés within the interaction are cumulatively significant, as captured by the principle of positionality and exemplified by the indication of a sedimenting of Andrés' status as a marginalized and perhaps problematic student. One is painfully aware of the principle of partialness in the case of Andrés, as the few examples here draw one very limited, situated picture of his identity and those of his co-participants. It is possible, or even likely, that other observers or other interactions might lead to different conclusions about Andrés and his co-participants, and it is also possible that contemporary or subsequent interactions would result in the emergence of new and different alignments and identities.

The present analysis suggests that, like Pichler's (2006) conclusions about adolescent teasing, impoliteness may be used by bilingual adolescents to attack each other's face. Furthermore, like Evaldsson's (2005) conclusions about pre-adolescent insults, insults in the data examined in this paper are co-constructed in interaction, and they are used to index membership in ethnoracial, national, and linguistic communities. The exclusion and community gate-keeping among the pre-adolescents examined here rely on the local context of the interaction and the wider context of the community of practice, while also indexing broader institutional and ideological frameworks involving, for example, nationality and standard language.

Arizona State University

\section{Appendix}

\section{Transcription conventions}

plain

italics

bra[ckets

[

CAPS

*asterisks*

colon:::

hyphen-

...

(.) original talk

English translation of Spanish talk

overlapping talk

comparatively louder talk

comparatively quieter talk

lengthening of the preceding sound

self-interruption

lines not relevant to analysis eliminated from transcript very brief (micro) pause 
(1.0)

(single par.)

((double par.)) pause for number of seconds indicated

analyst's best guess at talk

analyst's comments, usually about non-verbal information

\section{Notes}

* I would like to thank the participants in the Accomplishing Bilingual Identity colloquium at the Sociolinguistics Symposium in Limerick, Ireland in July 2006, including the organizer Ashley Williams, Helena Bani-Shoraka, Katherine Chen, Tim Greer, as well as Lisa Del Torto, who joined the group after the symposium. It has been a challenging and rewarding intellectual collaboration. Thanks also to Mary Bucholtz and Kira Hall, who in addition to participating as discussants in the colloquium, also generously read and commented on earlier versions of this article and offered insights that helped to focus the argument of this paper. The collection of the data analyzed in this paper was made possible through a grant from the Sociological Initiatives Foundation, and my travel to the Sociolinguistics Symposium 16 in Limerick, Ireland was supported by a competitive seed grant from Arizona State University's Institute for Humanities Research.

1. This approach is exemplified by Gafaranga (2005, 2001), Cashman (2005b), Williams (2005) and Sebba and Wootton (1998), among many others.

2. Furthermore, like Bani-Shoraka (2005), she finds that a non-serious frame of teasing is used by participants to 'protect their own and other's face when approaching topics that tend to be perceived as sensitive or taboo by the group' (2005: 244), in this case romance, boys, and sex.

3. See Cashman (2006a) for a discussion of how these approaches differ and Terkourafi (2005) for a discussion of how the traditional view (Lakoff 1973; Brown and Levinson 1987; Leech 1983) and the 'postmodern view' (Eelen 2001; Mills 2003; Watts 2003) have common underlying assumptions, which are used as the basis of Terkourafi's 'frame-based view'.

4. The alternative terms included in parentheses are from Bucholtz and Hall (2005: 608).

5. It should be noted that Bucholtz and Hall (2005: 602-603) do, in fact, cite Bailey's (2000) work, which is an analysis of a Spanish-English bilingual context.

6. The term Hispanic is used here because it is the term used in the collection of data on ethnicity at the school, and it should in no way imply that this is a term that students use to self-identify.

7. These are pseudonyms, as are all the names used to refer to the children and the teachers.

8. See Cashman (2006b) for a discussion of the language policy banning bilingual education in Arizona.

9. Please see the Appendix for an explanation of the transcription conventions.

10. I am indebted to Tim Greer, who points out that Jessica might be doing a noticing (cf. Pomerantz 1980) that she assumes others around her will be interested in since they do not control the resource.

11. The fact that the approaching student uses English, like Andrés' use of Spanish, is most likely participant-related (i.e., due to proficiency) and not a discourserelated use of a contrasting code as a contextualization cue (cf. Auer 1984). The student, a native English speaker, rarely used Spanish in the corpus and, when she did, only used one or two lexical insertions. 
12. Davies (2005) describes the hierarchical nature of some communities of practice and the gate-keeping role of core members vis-à-vis peripheral members.

13. This is similar to Yesenia's locally accomplished identity of bilingual arbiter described in Cashman (2005b). See also Bucholtz (2007) on the iconic word güey in Mexican Spanish.

\section{References}

Auer, Peter (1984). Bilingual Conversation. Amsterdam: John Benjamins.

Bani-Shoraka, Helena (2005). Language choice and code-switching in the Azerbaijani community in Tehran: A conversation analytic approach to bilingual practices. Studia Iranica Upsaliensia 9.

Bailey, Benjamin (2000). Language and negotiation of ethnic/racial identity among Dominican Americans. Language in Society 29, 555-582.

Bourdieu, Pierre (1990). The Logic of Practice. Stanford: Stanford University Press.

Brown, Penelope and Stephen C. Levinson (1987). Politeness: Some Universals in Language Usage. Cambridge: Cambridge University Press.

Bucholtz, Mary (2007). Indexing gender and youth style through slang. In Gunnarson, Britt-Louise, Sonja Entzenberg, and Maria Ohlsson (eds.), Språk och kön i nutida och historiskt perspektiv: Studier presenterade vid den sjätte nodiska konferensen om språk och kön, Uppsala, den 6-7 oktober 2006 ['Languge and gender in present-day and historical perspective: Studies presented at the Sixth Nordic Conference on Language and Gender, Uppsala, October 6-7'], University of Uppsala, $11-32$.

Bucholtz, Mary and Kira Hall (2004a). Language and identity. In Duranti, Alessandro (ed.), A Companion to Linguistic Anthropology. Malden, MA: Blackwell, 369-394.

- (2004b). Theorizing identity in language and sexuality research. Language in Society $33,469-515$.

- (2005). Identity and interaction: A sociocultural linguistic approach. Discourse Studies 7(4-5), 585-614.

Cashman, Holly R. (2005a). Aggravation and disagreement: A case study of a bilingual, cross-sex dispute. Southwest Journal of Linguistics 24(1), 31-51.

- (2005b). Identities at play: Language preference and group membership in bilingual talk-in-interaction at play. Journal of Pragmatics 37(3), 301-315.

- (2006a). Impoliteness in children's interactions in a Spanish/English bilingual community of practice. Journal of Politeness Research 2(2), 217-246.

- (2006b). Who wins in research on bilingualism in an anti-bilingual state? Journal of Multilingual and Multicultural Development 27(1), 42-58.

Cromdal, Jakob (2004). Building bilingual oppositions: code-switching in children's disputes. Language in Society 33, 33-58.

Culpeper, Jonathan (1996). Towards an anatomy of impoliteness. Journal of Pragmatics $25,349-367$.

- (2005). Impoliteness and entertainment in the television quiz show: The Weakest Link. Journal of Politeness Research 1, 35-72.

Culpeper, Jonathan, Derek Bousfield, and Anne Wichmann (2003). Impoliteness revisited: With special reference to dynamic and prosodic aspects. Journal of Pragmatics $35,1545-1579$.

Davies, Bethan (2005). Communities of practice: Legitimacy not choice. Journal of Sociolinguistics 9(4), 557-581.

Eckert, Penelope (2000). Linguistic Variation as Social Practice. Malden, MA: Blackwell. 
Eckert, Penelope and John R. Rickford (eds.) (2001). Style and Sociolinguistic Variation. Cambridge: Cambridge University Press.

Eelen, Gino (2001). A Critique of Politeness Theories. Manchester: St. Jerome's Press.

Evaldsson, Ann-Carita (2005). Staging insults and mobilizing categorizations in a multiethnic peer group. Discourse and Society 16(6), 763-786.

Gafaranga, Joseph (2001). Linguistic identities in talk-in-interaction: Order in bilingual conversation. Journal of Pragmatics 33(12), 1901-1925.

- (2005). Demythologising language alternation studies: Conversational structure vs. social structure in bilingual interaction. Journal of Pragmatics 37(3), 281-300.

García Bedolla, Lisa (2003). The identity paradox: Latino language, politics and selective dissociation. Latino Studies 1, 264-283.

Gardner-Chloros, Penelope and Katerina Finnis (2003). How code-switching mediates politeness: Gender-related speech among London Greek-Cypriots. Estudios de Sociolingüistica 4(2), 505-532.

Goffman, Erving (1967). Interaction Ritual: Essays on Face-to-face Behavior. Garden City, New York: Anchor Books.

Gumperz, John J. (1982). Discourse Strategies. Cambridge: Cambridge University Press.

Gumperz, John J. and Jenny Cook-Gumperz (2005). Making space for bilingual communicative practice. Intercultural Pragmatics 2(1), 1-23.

Labov, William (1963). The social motivation of sound change. Word 19, 273-309.

- (1966). The Social Stratification of English in New York City. Washington, D.C.: Center for Applied Linguistics.

Lakoff, Robin (1973). The logic of politeness; or minding your p's and q's. Paper from the Ninth Regional Meeting of the Chicago Linguistic Society. Chicago: Chicago Linguistic Society, 292-305.

Leech, Geoffrey (1983). Principles of Pragmatics. London: Longman.

Levinson, Stephen (1992). Activity types and language. In Drew, Paul and John Heritage (eds.), Talk at Work, Cambridge: Cambridge University Press, 66-100.

Li Wei (2005). 'How can you tell?' Towards a common sense explanation of conversational code-switching. Journal of Pragmatics 37(3), 375-389.

Lippi-Green, Rosina (1997). English with an Accent: Language, Ideology, and Discrimination in the United States. London/NY: Routledge.

Locher, Miriam A. (2004). Power and Politeness in Action: Disagreements in Oral Communication. Berlin: Mouton de Gruyter.

Locher, Miriam A. and Richard J. Watts (2005). Politeness theory and relational work. Journal of Politeness Research 1(1), 9-33.

MacGregor-Mendoza, Patricia (1998a). The criminalization of Spanish in the United States. In Kibbee, Douglas (ed.), Language Legislation and Linguistic Rights. Amsterdam: John Benjamins, 55-67.

- (1998b). Language and the bilingual teacher: Use, attitudes, roles. Southwest Journal of Linguistics 17(2), 83-99.

Mills, Sara (2003). Gender and Politeness. Cambridge: Cambridge University Press.

Pichler, Pia (2006). Multifunctional teasing as a resource for identity construction in the talk of British Bangladeshi girls. Journal of Sociolinguistics 10(2), 225-249.

Pomerantz, Anita (1980). Telling my side: 'Limited access' as a 'fishing device'. Sociological Inquiry 50(3-4), 186-198.

Reyes, Angela (2005). Appropriation of African American slang by Asian American youth. Journal of Sociolinguistics 9(4), 509-532.

- (2007). Language, Identity and Stereotype among Southeast Asian American Youth: The Other Asian. Mahwah, NJ: Lawrence Erlbaum.

Schilling-Estes, Natalie (2004). Constructing ethnicity in interaction. Journal of Sociolinguistics 8(2), 163-195. 
Sebba, Mark and Anthony Wootton (1998). We, they and identity: Sequential versus identity-related explanation in codeswitching. In Auer, P. (ed.), Codeswitching in Conversation. London: Routledge, 262-289.

Terkourafi, Marina (2005). Beyond the micro-level in politeness research. Journal of Politeness Research 1(2), 237-262.

Trujillo, Armando (2005). Politics, school philosophy and language policy: The case of Crystal City schools. Educational Policy 19(4), 621-654.

Watts, Richard J. (2003). Politeness. Cambridge: Cambridge University Press.

Weisman, Evelyn (2001). Cultural identity and language attitudes: Perspectives of four Latina teachers. Urban Education 36(2), 203-225.

Williams, Ashley M. (2005). Fighting words and challenging expectations: Language alternation and social roles in a family dispute. Journal of Pragmatics 37, 317328.

Zentella, Ana Celia (2003). 'José, can you see?': Latina responses to racist discourse. In Somer, Doris (ed.), Bilingual Aesthetics. NY: Palgrave, 51-66. 
Copyright of Multilingua is the property of Walter de Gruyter GmbH \& $\mathrm{Co}$. KG. and its content may not be copied or emailed to multiple sites or posted to a listserv without the copyright holder's express written permission. However, users may print, download, or email articles for individual use. 